\title{
ПРОБЛЕМА ПСИХОСОМАТИЧНИХ СПІВВІДНОШЕНЬ У ХВОРИХ НА ІШЕМІЧНУ ХВОРОБУ СЕРЦЯ
}

\author{
๑О. С. Юрценюк, Н. С. Карвацька, С. Д. Савка, С. С. Ротар, В. І. Курик \\ вДнз України «Буковинський державний медичний університет», Чернівці
}

РЕЗЮМЕ. В статті розглянута проблема психосоматичних співвідношеньу кардіологічній практиці. В результаті проведеного дослідження встановлено рівні особистісної тривоги, реактивної тривожності, алекситимії у хворих на інфаркт міокарда. Виявлено головні типи реагування на хворобу у даної когорти пацієнтів. Сформульовано висновки.

КЛЮчОВІ СЛОВА: психосоматика, ішемічна хвороба серця, інфаркт міокарда, депресія, тривога, алекситимія, типи відношення до хвороби.

Вступ. Проблема психосоматичних співвідношень, що стосується зв'язку між тілом та психікою, $\epsilon$ предметом дискусії не тільки в галузі психіатрії, а й в загальній патології людини [5]. Ішемічна хвороба серця (IXC) та інфаркт міокарда належать до психосоматичної патології. Це означає, що соматичне захворювання розвивається за постійної та безпосередньої участі психічного фактора [1]. Розлади, які належать до психосоматичних, включають не тільки психосоматичні захворювання в традиційному, вузькому розумінні цього терміна, а й ширше коло порушень: соматизовані розлади, соматичні захворювання, патологічні психогенні реакції, такі як тривожність, алекситимія, астенія, істерія, обсесивно-фобічні порушення, депресії. Тривога - центральний елемент в механізмі формування психічного стресу. Роль тривоги як сигналу неблагополуччя та небезпеки криється в тому, що вона активізує процеси психічної адаптації $[7,8]$. Слід розрізняти індивідуальні психологічні особливості хворого та патологічне реагування на хворобу. Тому при оцінці результатів слід враховувати характерологічні особливості пацієнта та його психологічний стан до захворювання $[9,12]$. Астенічний стан - це різноманітні симптоми нервово-психічної слабкості, які включають розлади сну, дратівливість, підвищену втомлюваність, відзначається особистісна компонента астенії, пов'язана із усвідомленням хвороби, стурбованістю, очікуванням наступного нападу стенокардії чи повторного інфаркту [13]. Обсесивно-фобічний тип реагування проявляється хворобливим страхом, який зумовлений захворюванням, боязню померти та іншими побоюваннями, які пов'язані з захворюванням, гіпертрофованою оцінкою його наслідків, що загрожують життю [4]. Невротично-депресивний варіант визначається тривогою та відчуттям безнадійності, які часто поєднуються з астенією, зниженням фізичної активності, алергічними реакціями, песимістичним сприйняттям хвороби, тривожними побоюваннями і страхами, уявлення- ми про небезпеку хвороби, ії невиліковність, негативні соціальні наслідки, зазвичай перебільшені $[11,13]$. При істеричному типі реагування домінують ідеї "повного відновлення будь-якою ціною", хворі відчувають у собі потенційні можливості силою волі “переломити” хід подій, позитивно вплинути на процес лікування $[5,6]$

Одним з психологічних факторів, що сприяють розвитку IXC, $\epsilon$ алекситимія. Алекситимія характеризується утрудненням або нездатністю людини точно описувати власні емоційні переживання і розуміти почуття іншої людини, труднощами визначення різниці між почуттями та фізичними відчуттями, фіксацією на зовнішніх подіях на шкоду внутрішнім переживанням. Недостатне усвідомлення емоцій призводить до фокусування емоційного збудження на соматичній компоненті та розвитку психосоматичних розладів [2].

Мета дослідження. Вивчення рівнів тривоги, алекситимії у хворих на інфаркт міокарда, а також дослідження типів реагування на хворобу у даного контингенту хворих для подальшого коректного планування лікувальних та профілактичних заходів.

Матеріал і методи дослідження. Робота базується на обстеженні 130 хворих (70 чоловіків та 60 жінок), які перебували на стаціонарному лікуванні в відділенні інтенсивної терапії Чернівецького обласного клінічного кардіологічного диспансеру з діагнозом гострий інфаркт міокарда, стенокардія напруги II-IV ФК, післяінфарктний кардіосклероз.

Ретельно проводився збір анамнезу. Рівень особистісної та ситуативної тривожності встановлювали за методикою Чарльза Спілбергера [3]. Алекситимію визначали за допомогою Торонтської алекситимічної шкали, адаптованої в інституті ім. В. М. Бехтерева [3]. Для визначення типів реагування на хворобу використовували тест для виявлення невротичних станів (К. К. Яхін, Д. М. Менделевич) [3]. 
Огляди літератури, оригінальні дослідження, погляд на проблему

Результати й обговорення. Встановлено, що серед хворих на інфаркт міокарда більшість складають особи з високим рівнем особистісної тривожності (ВРОТ) - 61,53\%, середній рівень особистісної тривожності (СРОТ) виявлений у $38,47 \%$ випадків, низького рівня тривожності в обстежених хворих не виявлено взагалі. Серед чоловіків частки пацієнтів I та II груп були практично однаковими (47,37 \% пацієнтів з ВРОТ та $52,63 \% 3$ СРОТ), на відміну від жінок, серед яких переважали особи з ВРОТ (71,43 \% проти $28,57 \%$ з СРОТ). Прикметно, що в підгрупах з ВРОТ та СРОТ абсолютні значення також були вищими у жінок, ніж у чоловіків $(-56,73+2,11)$ проти $(49,33+1,84)$ балів $(p<0,05)$ для осі6 з ВРОТ, та $(38,66+1,48)$ проти $(38,0+1,36)(p<0,05)$ для осіб з СРОТ.

Серед чоловіків I групи переважали особи з високим рівнем ситуативної тривожності (ВРСТ) $55,5 \%$ на відміну від II групи, де ВРСТ мали $25 \%$ чоловіків; у жінок результати були відповідно 33,3 \% проти $16,6 \%$. Серед осіб I групи частки чоловіків та жінок з ВРСТ були відповідно 55,5 \% проти 33,3 \%. У II групі частки чоловіків з ВРСТ були теж значно вищими, ніж у жінок, відповідно $25 \%$ проти $16,6 \%$. Отже, рівень ситуативної тривожності більше виражений у чоловіків (55,5\% проти $33,3 \%$ ), на відміну від жінок, у яких високою була особистісна тривожність (71,42 \% проти 47,37 \%).

Безпосередніми причинами розвитку інфаркту міокарда в I групі були фізичне навантаження $(3,84 \%$ випадків), емоційне перенапруження $(84,61 \%) ; 11,53$ \% хворих не можуть пов'язати виникнення інфаркту з конкретним чинником. У осіб II групи фізичне навантаження призвело до розвитку інфаркту міокарда в 57,14 \% випадків, в 21,42 \% причиною інфаркту стали емоційне перенапруження, видимої причини інфаркту не можуть вказати 21,42 \% пацієнтів.

При аналізі проблеми алекситимії у осіб з ВРОТ виявлено, що жінки легше знаходять слова для вираження своїх почуттів, ніж чоловіки, відповідно алекситимія виявлена у 26,6 \% жінок та у 65,6 \% чоловіків. Серед осіб II групи спостерігаються подібні результати: алекситимія зустрічається в 16,6 \% у жінок, у 50 \% чоловіків. Серед пацієнтів I групи виявлено алекситимічних $61,5 \%$ $(77,43 \pm 7,16) ;$ неалекситимічних - 38,46 \% $(57,8 \pm 7,15)$ осіб. Прикметно, що високий рівень ситуативної тривожності був притаманний $32,5 \%$ $(54,85 \pm 4,88)$ всіх пацієнтів, з них $78,57 \%(78,0 \pm 7,51$ бали) алекситимічних та $21,42 \%(61,0 \pm 1,14$ бали) неалекситимічних хворих.

Враховуючи типи реагування на хворобу встановлено, що пацієнти з тривожним типом реагування на хворобу (чол. $+1,2$; жін. $-0,4)$ найчастіше скаржились на серцебиття, порушення сну підвищену втомлюваність та пітливість, відповідно у $81,8 \%, 86,3 \%, 77,2 \%, 63,6 \%$, тоді як найбільша різниця між значенням здоров'я та нездоров'я відмічалися у таких скаргах як погіршання пам'яті, серцебиття, пітливість. Задишку відзначали у себе 70 \% опитаних.

При істеричному типі реагування на хворобу (жін. -3,8 чол. $+1,5)$ найхарактернішими скаргами були: підвищена втомлюваність (90\%), зниження працездатності (90\%), порушення сну (75 \%) та похитування при ходьбі (75 \%); запаморочення, погіршення пам'яті та підвищена пітливість, відповідно у $65 \%$, $45 \% .60 \%$.

Для людей 3 невротично-депресивним типом реагування на хворобу (жінки -2,7 чоловіки $+1,2)$ найхарактерніші скарги на серцебиття $(90,4 \%)$, зниження працездатності (90,4 \%), порушення сну $(85,7 \%)$, виражений головний біль $(80,9 \%)$, пітливість (61, 9\%), тоді як зниження апетиту відмічали у себе 38 \% - нездоров'я та 0 - здоров'я, запаморочення та порушення пам'яті відповідно $57,1 \%, 42,8 \%$.

Пацієнти з астенічним типом реагування на хворобу (жін.-3, чол.+2) скаржаться на підвищену втомлюваність (90,9 \%), порушення сну $(86,3 \%)$, зниження працездатності $(81,8 \%)$, серцебиття $(81,8 \%)$, похитування при ходьбі $(71,2 \%)$. На зниження апетиту скаржаться 36,3 \% опитаних, в той час як про нормальний апетит не говорив ніхто. Пітливість та погіршення пам'яті спостерігали у себе відповідно 63,6 \% та 36,3 \% хворих .

Всі типи реакцій на хворобу супроводжувались різноманітними вегетативними розладами, які були характерні як для жінок $(-7,2)$, так і для чоловіків $(-5,8)$. Більшість опитаних скаржились на підвищену втомлюваність та зниження працездатності (89,4 \%), задишку та серцебиття $(84,2 \%)$, запаморочення (73,6 \%), порушення сну $(68,4 \%)$, запори (36,8 \%), пронос (15,7\%).

Висновки. 1. Високий рівень особистісної тривожності $\epsilon$ більш характерним для жінок $(71,43 \%)$, на відміну від чоловіків, у яких при меншому рівні особистісної тривожності $(47,37 \%)$ значно переважає тривожність ситуативна (55,55\%).

2. Найчастіше невротичні реакції виявляються у вигляді невротичної депресії, астенії, істерії, які супроводжуються вираженими вегетативними порушеннями.

3. У жінок, на відміну від чоловіків, перебіг ішемічної хвороби серця значно частіше супроводжується невротичними реакціями різних видів, що, очевидно, пояснюється більшою чутливістю, лабільністю жіночої психіки та схильністю жінок до більш емоційної оцінки власного стану.

4. Визначення типу реакції на хворобу у паці$\epsilon$ ттів з ІХС дозволяє правильно оцінити суб'єКтивні 
Огляди літератури, оригінальні дослідження, погляд на проблему

прояви основного захворювання та відмежувати скарги, які обумовлені психологічними чинниками та характерологічними особливостями пацієнта.
Перспективи подальших досліджень. У подальшому буде досліджено вплив нового комплексного лікування на рівень тривоги та алекситимії у хворих на інфаркт міокарда.

\section{ЛІТЕРАТУРА}

1. Нециркулярні депресії : монографія / О. К. Напрєєнко, К. М. Логановський, О. Г. Сиропятов / за ред. проф. Напрєєнка О. К. - К. : Софія-А, 2013. - 624 с.

2. Пінчук І. Я. Сучасний стан психологічного забезпечення населення України / І. Я. Пінчук, Ю. В. Ячнік // Архів психіатрії. - 2016. - Том 22, № 1 (84). - С. 28-34.

3. Семиченко В. А. Психические состояния / В. А. Семиченко. - К., 1998. - 208 с.

4. Суксиасян С. Г. Соматизированные психические нарушения / С. Г. Суксиасян, Н. Г. Манасян, С. С. Чшмаритян // Журнал неврологии и психиатрии им. С. С. Корсакова. - 2001 - № 2 - С. 57-61.

5. Современные реалии по оказанию помощи пациентам с депрессией: итоги первого года внедрения национального протокола / О. С. Чабан, Л. Н. Юрьева, Е. А. Хаустова // Архів психіатрії. - 2015. - Т. 21, № 3-4 (82-83). - C. 25-30.

6. Юрценюк О. С. Спеціальна (нозологічна) психіатрія : навчальний посібник / О. С. Юрценюк. - Чернівці : БДМУ, 2016-120 c.

7. Юрценюк О. С. Тривожні та депресивні розлади у хворих на артеріальну гіпертензію (огляд літератури) / О. С. Юрценюк, Н. І. Пастернак // Клінічна та експериментальна патологія. - 2016. - Т. XV - № 1 (55). - С. 201-205.
8. Acute myocardial infarction: psyhocial and carsiovascular risk factors in men / R. Coelho, E. Ramos, J. Prata [et al.] // J. Carsiovasc. Risk. - 1999. Vol. 6 (3). - P. 157-162.

9. Failde I. Validity and reliability of the SF-36 Health Surgey Questionnaire in patients with coronary artery disease / I. Failde, I. Ramos // J. Clin. Epidemiol. - 2013. Vol. 534 - P. $359-365$.

10. Comparison of anxiety assessments between clinicians and patients with acute myocardial infarction in cardiac critical care units / J. O'Brien, D. Moser, B. Riegel, [et al.] //Am. J. Crit. Care. - 2012. - Vol. 10(2). - P. 97-103.

11. Persistent impaired emotional functioning in survivors of a myocardial infarction? / C. Plevier, J. Mooy, P. Marang-Van de Mheen [et al.] // Qual Life Res. - 2015. Vol. 10(2). - P.123-132.

12. Sex differences in chest pain in patients with documented coronary artery disease and exercise-induced ischemia: Results from the PIMI study/D. Sheps, P. Kaufmann, D. Sheffield [et al.] // Am. Heart J. - 2009. - Vol. 142, № 5. P. 864-871.

13. Stiefelhagen $P$. The post-infarction patient. When anxiety handicaps daily life / P. Stiefelhagen // MMW Fortschr Med. - 2011. - Vol. 11, № 1-2. - P. 4-6.

\section{THE PROBLEM OF PSYCHOSOMATIC RELATIONS OF PATIENTS WITH CORONARY HEART DISEASE}

\section{O. S. Yurtseniuk, N. S. Karvatska, S. D. Savka, S. S. Rotar, V. I. Kuryk Bukovynian State Medical University, Chernivtsi}

SUMMARY. The article deals with the problem of psychosomatic relations in cardiology practice. The research shows the levels of personal anxiety, reactive anxiety, alexithymia of the patients with myocardial infarction. Main types of responses to the disease are discovered in this number of patients. The conclusions are summarized.

KEY WORDS: psychosomatics, coronary heart disease, myocardial infarction, depression, anxiety, alexithymia, the types of disease attitudes. 